\title{
KULTUR PRIMER FIBROBLAS: PENELITIAN PENDAHULUAN
}

\author{
Yuli Kurniawati ${ }^{1}$, Sudigdo Adi $^{1}$, Achadiyani $^{1}$, Oki Suwarsa ${ }^{1}$, \\ Dimas Erlangga ${ }^{2}$, Tenny Putri ${ }^{2}$
}

\begin{abstract}
Abstrak
Kultur sel fibroblas banyak digunakan untuk penelitian proses penyembuhan luka dan penuaan kulit. Metode ini digunakan untuk melihat perkembangan sel, proliferasi kinetik seluler, serta biosintesis komponen matriks ekstraseluler. Penelitian pendahuluan ini dilakukan untuk optimasi teknik laboratorium serta berbagai kendala yang didapatkan saat kultur fibroblas. Kultur primer fibroblas dibagi menjadi 2 jenis sampel yaitu sampel yang berasal dari embrio mencit usia 7,59,5 hari, dan kulit pasien keloid. Sampel dari embrio mencit dilakukan kultur primer dengan metode dissociated fibroblast. Sampel jaringan keloid dan kulit normal dikultur dengan metode skin explant. Fibroblas yang berasal dari kultur primer embrio mencit tumbuh baik sehingga dapat dilakukan subkultur dan disimpan di dalam nitrogen cair suhu $-198^{\circ} \mathrm{C}$. Fibroblas yang berasal dari sampel keloid pertama tumbuh sesuai pola pertumbuhan fibroblas, namun pada sampel kedua terdapat kontaminasi Paecilomyces sp. yang merupakan salah satu jenis jamur kontaminan. Sel fibroblas mudah untuk dikultur karena memiliki kemampuan tumbuh dan melekat yang tinggi serta regenerasi cepat, namun penelitian lebih lanjut untuk optimasi teknik kultur dan pencegahan kontaminasi masih dibutuhkan sehingga sel dapat tumbuh baik.
\end{abstract}

Kata kunci: kultur fibroblas, skin explant, Dissociated fibroblast, kontaminasi

\begin{abstract}
Fibroblast cell culture method has been used for wound healing and skin aging studies. This method was used for cell development imaging study, celullar kinetic proliferation and extracelullar matrix component biosynthesis. This preeliminary study was done for laboratorical technic optimation as well as problems appeared in fibroblast culture. Fibroblasts primary culture was divided into 2 type of samples, from 7.5-9.5-day-mice embryo and keloid-patient skin. Primary culture with dissociated fibroblast method was done for mice embryo sample. Keloid tissue sample and normal skin were cultured with skin explant method. Fibroblasts that were taken from mice embryo primary culture grew well therefore subculture can be done and kept in $198^{\circ} \mathrm{C}$ liquid nitrogen storage. Fibroblasts that were taken from first keloid sample grew according to fibroblast growth pattern, but, there was contamination with Paecilomyces sp. which was one of the contaminating fungi. Fibroblast cells are easy to be cultured as they have growth ability and high adhesion capability as well as rapid regeneration, but, further study for cultured technical optimation and contamination prevention are still neededthereforethe cells can grow well.
\end{abstract}

Keywords: fibroblast culture, skin explant, dissociated fibroblast, contamination. 


\section{PENDAHULUAN}

Fibroblas merupakan sel yang banyak didapat pada jaringan ikat terutama pada kulit. Sel fibroblas terlibat secara aktif dalam pembentukan seratserat terutama serat kolagen dan matriks amorf ekstraseluler. Selain itu fibroblas menghasilkan serat-serat retikulin, elastin, glikosamin, dan glikoprotein dari substansi interseluler amorf. Fibroblas terlibat dalam pertumbuhan normal, proses penyembuhan luka dan aktifitas fisiologis dari tiap jaringan dan organ dalam tubuh. Fungsi utama fibroblas adalah menjaga integritas jaringan pendukung dengan cara mengatur perubahan umur matriks ekstraseluler secara berkesinambungan. Sel fibroblas mudah untuk dikultur karena memiliki kemampuan tumbuh dan melekat yang tinggi dan regenerasi cepat. ${ }^{1}$

Kultur sel fibroblas telah banyak digunakan antara lain untuk penelitian proses penyembuhan luka, mekanisme penuaan kulit. Metode ini banyak digunakan untuk melihat perkembangan sel, proliferasi kinetik seluler serta biosintesis komponen matriks ekstraseluler. $^{2,3,4}$ Sel yang diperoleh secara langsung dari pasien dan tumbuh pada medium kultur disebut sebagai kultur primer. Berbeda dengan biakan keratinosit, fibroblas lebih mudah tumbuh dan dapat dilakukan subkultur. Subkultur fibroblas dilakukan dengan memindahkan fibroblas murni dari petridesk kultur primer ke dalam medium segar kemudian ditempatkan dalam petridesk baru untuk memulai pertumbuhan kembali. Media yang banyak digunakan untuk transport dan media pertumbuhan fibroblas adalah Dulbecco's Modified Eagle Medium (DMEM), atau Roswell
Park Memorial Institute (RPMI). Medium ini ditambahkan penisilin, streptomisin dan fetal bovine serum (FBS) atau fetal calf serum (FCS ). ${ }^{1,2}$

Teknik kultur primer fibroblas ada 2 cara yaitu skin explant dan dissociated fibroblast. Pada skin explant, fibroblas ditumbuhkan dari kulit langsung. Spesimen kulit yang sudah dipotong halus diletakan pada media partumbuhan dan diamati pertumbuhannya sesuai prosedur. Cara kultur dissociated fibroblast lebih rumit dari skin explant. Pemisahan epidermis dilakukan dengan cara dispase, fibroblas di lapisan dermis dipisahkan dengan proses enzimatik menggunakan tripsin atau kolagenase. Setelah dilakukan proses enzimatik lalu spesimen diletakkan di media kultur. Pada proses enzimatik ini harus dilakukan hati-hati dengan memperhatikan jenis tripsin yang dipakai, konsentrasi yang tepat dan masa inkubasi agar sel dapat tumbuh maksimal. Dissociated fibroblast merupakan tehnik yang lebih sering dipakai pada penelitian yang memerlukan jumlah fibroblas dalam jumlah banyak. ${ }^{2,5}$

Beberapa teknik kultur fibroblas telah dilakukan di Laboratorium Kultur Sel dan Jaringan FK UNPAD Bandung dengan berbagai sampel antara lain kulit normal, keloid dan embrio mencit. Penelitian pendahuluan ini dilakukan untuk mempelajari optimasi tehnik laboratorium serta berbagai kendala yang didapatkan pada saat kultur fibroblas.

\section{METODE}

Kultur primer fibroblas dibagi menjadi 2 bagian berdasarkan sampel 
yaitu sampel yang berasal dari embrio mencit usia 7,5 - 9,5 hari, dan kulit pasien keloid. Sampel yang berasal dari embrio mencit dilakukan kultur primer dengan metode Dissociated fibroblast. Pasien keloid telah mendapat penjelasan dan menandatangani informed concent, sebelum dilakukan eksisi elips lesi keloid. Selanjutnya sampel jaringan keloid dan kulit normal tersebut dikultur dengan metode skin explant.

\section{Kultur embrio mencit dengan metode dissociated fibroblast}

Pengambilan embrio mencit dilakukan di laboratorium hewan, embrio mencit dimasukan kedalam tabung falcon $50 \mathrm{~mL}$ yang berisi $15 \mathrm{~mL}$ PBS yang mengandung antibiotik. Selama proses pengambilan embrio, harus dipastikan media transfer selalu dalam keadaan dingin (tempatkan dalam ice bath). Pemisahan organ embrio dapat dilakukan di meja kerja. Bagian embrio yang akan dikultur hanya bagian badan embrio mencit. Badan embrio mencit dimasukkan ke dalam tabung Falcon 50 $\mathrm{ml}$ berisi $15 \mathrm{ml}$ PBS yang baru. Persiapan kultur primer embrio mencit dilakukan di Biosafety cabinet (BSC). Badan embrio dicacah halus dengan menggunakan scapel steril, lalu masukan kedalam tabung Falcon yang telah berisi PBS $5 \mathrm{ml}$ dan dilakukan sentrifugasi 200 G selama 5 menit, buang supernatan lalu tambahkan PBS 5 $\mathrm{ml}$, setrifugasi dilakukan 3 kali. Supernatan dari pencucian terakhir dibuang, lalu tambahkan Tripsin EDTA $0,25 \%$ yang telah dihangatkan sebanyak $2 \mathrm{ml}$, lalu dilakukan vortex sebentar, kemudian masukkan ke dalam Water Bath (WB) bersuhu $37^{\circ} \mathrm{C}$ selama 5 menit. Bila masih terdapat gumpalan embrio, tambahkan waktu selama 5 menit di dalam WB. Selanjutnya tambahkan $10 \mathrm{ml}$ medium RPMI lengkap yang sudah dihangatkan terlebih dahulu. Suspensi sel tersebut dilakukan setrifugasi 200 G selama 5 menit, buang supernatan dan tambahkan $12 \mathrm{ml}$ medium RPMI lengkap (yang telah diresuspensi dengan 10\% Fetal Bovine Serum $+1 \%$ antibiotik Penicillin-Streptomisin $+1 \%$ Amphoterisin B/ Fungizone). Tanam suspensi sel ke dalam six well plate dan diinkubasi di dalam inkubator $37^{\circ} \mathrm{C}$ dengan $\mathrm{CO}_{2} 5 \%$. Setelah 30 menit diinkubasi, lakukan pengamatan sel fibroblas dengan menggunakan mikroskop inverted.

\section{Kultur primer fibroblas keloid dilaku- kan dengan metode skin explant}

Jaringan keloid yang dari hasil

eksisi langsung dimasukan kedalam tabung sentrifuge $50 \mathrm{ml}$ yang telah di isi PBS steril, lalu dicuci dengan cara menggoyangkan tabung secara perlahan. Pencucian dilakukan minimal 3 kali masing-masing selama 10 menit. Perlu diingat bahwa proses kulturisasi fibroblas harus dilakukan sesegera mungkin, tidak lebih dari 6 jam. Sampel diletakkan dalam cawan petridisk dan buang bagian epidermis dengan menggunakan gunting, skapel steril, sehingga jaringan fibrosa saja yang diambil lalu cuci kembali dengan PBS steril. Sampel diletakan dalam lid of a $100 \mathrm{~mm}$ tissue culture dish lalu potong kecil-kecil sebesar 2-3 $\mathrm{mm}^{2}$. Potongan sampel 5-10 diletakan pada $35 \mathrm{~mm}$ tissue culture dish (tutup sampel dengan $22 \mathrm{~mm}$ glass coverslip dengan hati-hati). Beberapa tetes media kultur DMEM/ RPMI $4^{\circ} \mathrm{C}$ ditambahkan dibawah cover glass, teteskan perlahan dari bagian tepi, 
Ialu tambahkan kembali 1-2 ml DMEM/ RPMI perlahan jangan sampai terendam. Kultur diletakkan dalam inkubator dengan kelembaban $37^{\circ} \mathrm{C}, 5 \% \mathrm{CO} 2$. Dalam kisaran 24-72 jam setelah isolasi, sel fibroblas akan menjadi sel fibroblas yang utuh. Morfologi fibroblas adalah sel berbentuk spindle dan tumbuh pada tepi bagian tepi explant. Pengecekan pertumbuhan fibroblas dilakukan setiap 3-4 hari dan ganti medium. Pertumbuhan fibroblas diamati, jika pertumbuhan fibroblas sudah merata sampai dasar dish kurang lebih $80 \%$ dapat dilakukan panen (subkultur).

A

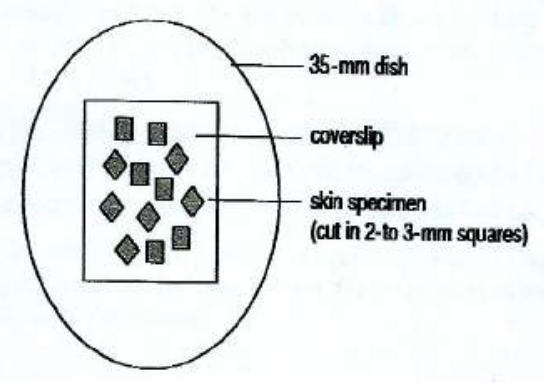

B

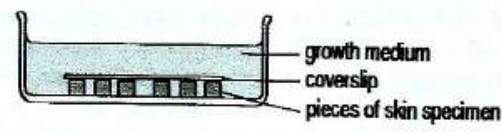

Gambar 1. Letak spesimen kulit pada media kultur. Sumber: Akira $\mathrm{T}^{2}$

\section{Panen sel / subkultur}

Panen sel atau subkultur dilakukan dengan cara sebagai berikut semua medium disedot pada petridesk, cuci dish dengan PBS steril, tambahkan tripsin 0,25\% dimasukkan sebanyak 1 $\mathrm{ml}$ kemudian diinkubasi dalam suhu $37^{\circ} \mathrm{C}$ selama $3-5$ menit akan terjadi perubahan bentuk sel dari bentuk kumparan menjadi bentuk bulat. Selanjutnya, masukkan medium lengkap sebanyak $3 \mathrm{ml}$, dan dilakukan pipeting

sampai semua sel lepas dari dasar dish dan membentuk suspensi sel. Suspensi sel diisap lalu dipindahkan kedalam tabung setrifuge steril untuk dilakukan sentrifugasi 150 G selama 10 menit, setelah itu supernatan dibuang. Pellet dari tabung diambil dan ditambahkan 100-200 $\mu$ medium kultur fresh $4^{\circ} \mathrm{C}$, lalu campurkan 10-20 $\mu \mathrm{l}$ suspensi sel dengan jumlah yang sama $0,4 \%$ trypanblue/PBS dalam tabung sentrifuge $50 \mathrm{ml}$. Hitung sel menggunakan hemositometer, untuk dilakukan subkultur maka sel yang hidup harus $>90 \%$. Setelah dilakukan penghitungan sel, masukkan $3-10 \times 10^{4}$ sel yang hidup ke dalam $5 \mathrm{ml}$ medium dalam $25 \mathrm{~cm}^{2}$ tissue culture flask. Medium diganti setiap 3-4 hari sampai pertumbuhan sel $60-80 \%$ untuk dapat dilakukan subkultur lagi.

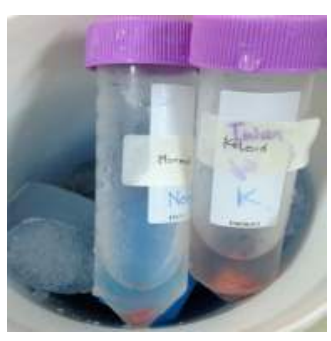

a.

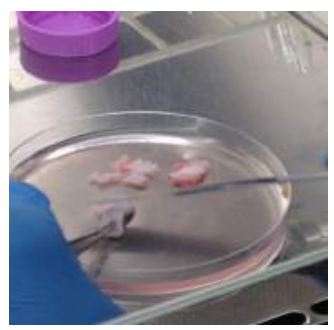

C.

Gambar 2. a. Spesimen kulit dalam PBS, b. Sampel kulit keloid, c. Pemisahan jaringan fibrous, d. Skin explant

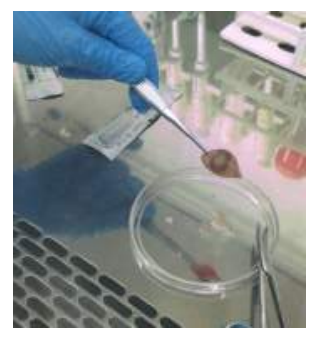

b.

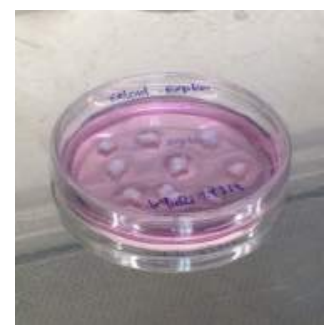

d. 
HASIL DAN PEMBAHASAN

\section{Hasil kultur primer embrio mencit.}

Setelah 30 menit diinkubasi dalam inkubator, sel fibroblas mencit telah menempel pada dasar well. Sel fibroblas mencit yang sudah konfluen dapat dilakukan subkultur lalu disimpan pada storage nitrogen cair $-196^{\circ} \mathrm{C}$.

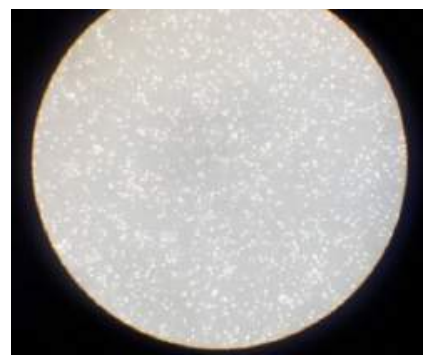

a.

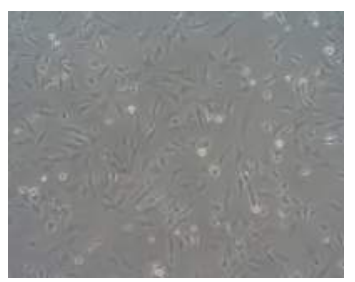

b.

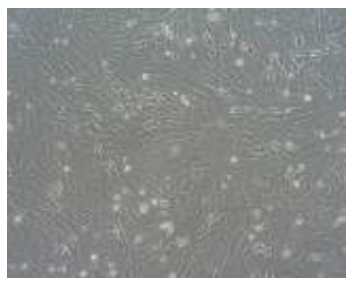

C.

Gambar 3. a. Fibroblas mencit setelah diinkubasi 30 menit, b. Fibroblas mencit 48 jam c. Fibroblas mencit 96 jam

\section{Hasil kultur primer skin explant:}

Dari sampel keloid pertama, sel fibroblas keloid tumbuh lebih cepat dari fibroblas kulit normal, pada hari ke-8 fibroblas keloid mulai tumbuh dari tepi explant sedangkan fibroblas kulit normal tumbuh pada hari 10 . Selanjutnya pada hari ke-15 pertumbuhan fibroblas keloid dan kulit normal mencapai kisaran $80 \%$ konfluen sehingga dilakukan subkultur. Pengamatan dilakukan pada hari ke-24 pertumbuhan fibroblas lambat dan pada hari ke-36 pertumbuhan fibroblas ber- henti. Berikut gambar fibroblas yang dihasilkan dari kultur.

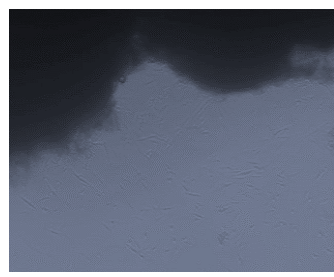

a.

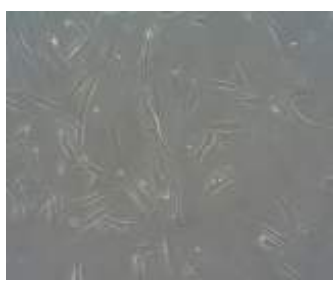

c.

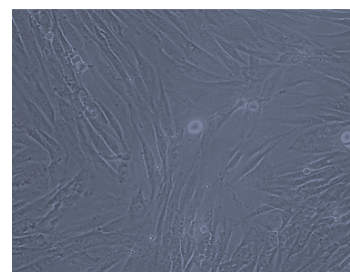

b.

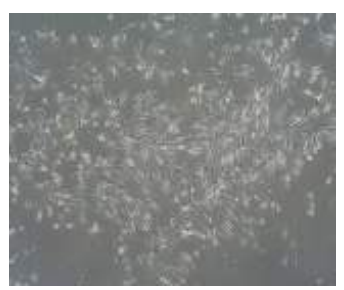

d.
Gambar 4. a. Fibroblas keloid hari ke 8, b. Fibroblas keloid hari ke 14, c. Fibroblas keloid subkultur 1, d. Fibroblas kulit normal hari ke 14.

Hasil kultur pada sampel keloid kedua, pertumbuhan fibroblas dari tepi explant tampak pada hari ke 7 dan 9 . Pertumbuhan fibroblas tidak subur dan ternyata pada hari ke 14 ditemukan kontaminasi jamur pada satu persatu petridesk. Skin explant yang terkontaminasi jamur dilakukan pemeriksaan di laboratorium mikologi untuk dilaku-kan identifikasi jamur penyebab kontaminasi. Hasil identifikasi jamur kontaminan yang ditemukan adalah Paecylomyces sp.

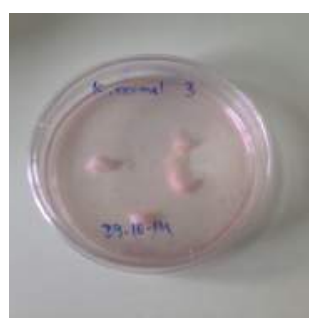

a.

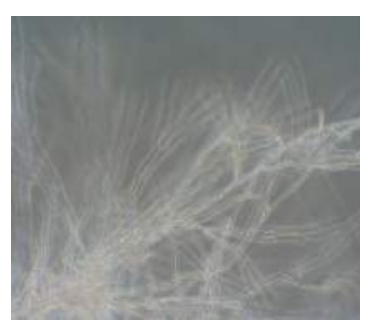

b.
Gambar 5. a. Kontaminasi jamur, b. Hifa pada petrideks skin explant 
Pertumbuhan fibroblas mencit yang dilakukan tumbuh sesuai partumbuhan fibroblas pada umumnya. Fibroblas yang berasal dari embrio mencit tumbuh cepat dalam waktu 24-72 jam dan dapat dilakukan subkultur lebih dari 10 kali. Subkultur (passage) dilakukan apabila sel yang tumbuh sudah mencapai $80 \%$. Fibroblas dapat disimpan pada nitrogen cair hingga 10 tahun dalam media 10\% DMSO/90\% FCS atau $10 \% \mathrm{MSO} /$ complete DMEM. Gambaran morfologi fibroblas berupa sel yang memanjang, inti yang berbentuk oval dan membentuk formasi linier atau bundle-like. Kecepatan pertumbuhan sel dalam kultur dipengaruhi oleh banyak faktor antara lain jenis sel primer yang akan dikultur, usia sampel, medium, teknik pengerjaan, faktor kontaminasi. ${ }^{1,2,6}$ Kultur primer dengan teknik skin explant dibandingkan dengan tehnik dissociated fibroblast menggunakan dispase dan atau kolagenase menghasilkan pertumbuhan sel yang lebih lama, jumlah sel yang lebih sedikit, namun karakteristik sel lebih baik dan terhindar dari kerusakan sel karena proses enzimatik. ${ }^{1,2,5}$

Penelitian mengenai keloid dilakukan dengan berbagai cara, metode penelitian yang sering dilakukan adalah dengan penelitian dasar dengan menggunakan hewan coba dan kultur jaringan. ${ }^{4,7}$ Kultur jaringan merupakan metode utama untuk penelitian fisiologi selular tanpa interferensi faktor lokal ataupun sistemik dalam organisme. Cara ini dapat mendeteksi mekanisme regulasi sel pada ekspresi gen dan tingkat cell signalling. Keloid hanya ditemukan pada manusia sehingga penelitian dengan hewan coba sangat sulit dilakukan. Penelitian keloid dengan menggunakan hewan coba memerlukan waktu yang cukup lama untuk menginduksi terbentuknya jaringan keloid. ${ }^{4,5}$

Pertumbuhan fibroblas dari skin explant rata-rata terjadi pada hari ketujuh. ${ }^{3,5}$ Pertumbuhan fibroblas keloid meningkat pada minggu ketiga dan jumlahnya menurun pada minggu kelima, sedangkan jumlah fibroblas kulit normal lebih banyak menurun dibandingkan fibroblas keloid. Setelah minggu ke-8 fibroblas mengalami degenerasi. Pada minggu ke-12 subkultur fibroblas kulit normal mengalami degenerasi sedangkan jumlah fibroblas keloid terus bertambah. ${ }^{7}$ Beberapa penelitian telah dilakukan untuk mengetahui lokasi lesi keloid yang akan diambil untuk dilakukan kultur. Hasil penelitian yang dilakukan oleh Giugliano dkk menyatakan kultur fibroblas tumbuh lebih cepat dari bagian tengah lesi keloid dibandingkan tepi lesi dan kulit normal. Peneliti lain menyatakan fibroblas yang berasal dari periperal lesi keloid ternyata menghasilkan produksi kolagen tipe I dan II yang lebih tinggi dibandingkan dengan intralesi dan ekstralesi. ${ }^{5,8}$ Pada penelitian pendahuluan ini dilakukan optimasi prosedur kultur fibroblas dan melihat morfologi fibroblas serta mempelajari kendala yang mungkin dapat timbul pada saat melakukan kultur. Kendala yang dapat ditemukan pada kultur sel adalah kontaminasi. Kultur fibroblas yang diambil dari biopsi kulit sering kali terkontaminasi oleh bakteri atau jamur. Kontaminasi tersebut dapat terjadi $20-63 \%$ dari kultur sel. Pada penelitian Brinzeu 2008 didapatkan kontaminasi mycoplasma $17.65 \%$, jamur $8.82 \%$ dan bakteri $5.88 \% .{ }^{9}$ Kontaminasi jamur lebih mudah dideteksi secara makroskopis pada petridesk tampak 
medium berubah warna menjadi kekuningan, lalu pertumbuhan miselium tampak seperti large fuzzypatches pada petridisk. Pemeriksaan dengan low power pembesaran mikroskop tampak hifa diantara fibroblas yang tumbuh.,9 Kontaminasi jamur dapat menghambat pertumbuhan fibroblas seperti yang terjadi sampel kedua. Untuk pencegah kontaminasi jamur umumnya dipakai agen antijamur seperti amphotericin B (Fungizone) dan mycostatin (Nystatin) dalam medium. Obat anti jamur tersebut hanya berfungsi untuk mencegah pertumbuhan jamur namun tidak dapat menghentikan pertumbuhan jamur bila sudah mengkontaminasi kultur. ${ }^{9}$ Pada sampel kulit keloid yang kedua terjadi kontaminasi jamur yang tumbuh perlahan bersamaan dengan pertumbuhan fibroblas, walaupun pada medium yang digunakan sudah ditambahkan fungizone. Penyebab kontaminasi jamur pada kultur sel primer antara lain tindakan aseptik antiseptik pada saat pengambilan sampel kulit yang kurang tepat, pencucian sampel, kontaminasi jamur dari medium, peralatan seperti tabung, petridisk, pipet, inkubator ataupun kontaminasi jamur dalam ruangan. Apabila telah terjadi kontaminasi maka medium, reagen, serta kultur yang terkontaminasi segera dibuang. Untuk mengurangi risiko kontaminasi secara umum maka dianjurkan beberapa langkah tindakan pertama lakukan teknik aseptik yang baik, kedua mengurangi kejadian dengan bekerja lebih berhatihati dan teliti, ketiga selalu menjaga kebersihan laboratorium, keempat secara rutin monitoring kontaminasi, kelima gunakan frozen cell repository, keenam strategic use of antibiotic. ${ }^{6}$

\section{SIMPULAN}

Sel fibroblas mudah untuk dikultur karena memiliki kemampuan tumbuh dan melekat yang tinggi dan regenerasi cepat. Kecepatan pertumbuhan sel dalam kultur dipengaruhi oleh banyak faktor antara lain jenis sel primer yang akan dikultur, usia sampel, medium, teknik pengerjaan, keahlian dan keterampilan tenaga laboratorium, serta faktor kontaminasi. Penelitian lebih lanjut mengenai cara kultur, teknik pengerjaan serta pencegahan kontaminasi sangat diperlukan agar dapat menghasilkan fibroblas yang dibutuhkan untuk penelitian selanjutnya.

\section{DAFTAR RUJUKAN}

1. Freshney RI. Culture of animal cells: a manual of basic tehnique. 5th ed.Willeyand Son, Inc.2005.

2. Akira T. Establishment of fibroblast cultures. Current protocols in cell biology. 1998; 2.1.1 -2.1 .12 .

3. Keira SM, Ferreira LM, Gragnani A, Duarte IS, Santos IAN. Experimental model for fibroblast culture. Acta Cir Bras. 2004;19:116

4. Bommie FS, Jun YL, Sung NJ. Models of abnormal scarring. BioMed Research International. 2013; article ID 423147, 8 pages.

5. Vanina MTV, Bernardo $H$, Jeronimo PF, Lydia MF. Keloid explant, culture: a model for keloid fibroblasts isolation and cultivation based on the biological differences of its specific regions. Int Wound J. 2010;7:339-48

6. Ryan J. Understanding and managing cell culture contamination. Corning Incorporated USA. 2008:1-24

7. Khorshid FA. Comparative study of keloid formation in humans and laboratory animals. Med Sci Monit. 2005;11(7):212-9

8. Syed, Ahmadi, Iqbal, Singh, Mc Grouther, Bayat. Fibroblast from the growing margin of keloid scars produce higher levels of 
collagen I and II compared with intralesional and extralesional sites: clinical implications for lesional site directedtherapy. British Jour of Dermatol. 2011;164:83-96
9. Brinzeu DGT, Feier V, Herbeck R, Cristodor $P$, Paunescu M, Condor A, Koreck A. Microbial and fungal contamination of keratinocyte and fibroblast cell cultures. Journal of Experimental Medical \& Surgical Research. 2008;3:123-8 